\title{
PENGARUH MANAJEMEN STRATEJIK SUMBER DAYA MANUSIA TERHADAP INOVASI DENGAN MANAJEMEN PENGETAHUAN SEBAGAI VARIABEL MEDIASI
}

\author{
Muhammad Harri *) \\ *) Dosen Program Studi Manajemen FE UNKRIS \\ Alamat: Kampus UNKRIS, Jatiwaringin Jakarta Timur \\ Email: mharri@unkris.ac.id
}

\begin{abstract}
The purpose of this research is to analyze the relationship of human resource strategic management and innovation, human resource strategic management and knowledge management, knowledge management and innovation, in addition to analyzing whether knowledge management can mediate the relationship of human resource strategic management with innovation Research data to be used is data of creative industry companies in Indonesia with primary data through questionnaires and secondary data published by the Government of Indonesia. The research sample is a creative industry company in Indonesia. The methods used are correlation analysis and regression to find out the relationship between variables and the analysis of pathways to find out the direct effects and indirect effects of human resource strategic management on innovation. The hypothesis of this research is (1) there is a positive relationship of human resource strategic management with innovation, (2) there is a positive relationship between the strategic management of human resources and knowledge management (3) there is a relationship between knowledge management and innovation (4) there is a positive relationship of human resource strategic management to innovation through knowledge management as a mediation variable. The findings provide evidence that knowledge management plays a mediating role between strategic human resource management and innovation.
\end{abstract}

Keywords: Strategic managemens of human resources, innovation and knowledge management

\section{PENDAHULUAN}

\begin{abstract}
Industri kreatif instrumen untuk menggerakkan perekonomian dan dapat dioptimalkan guna mengatasi kesenjangan sosial . Sektor industri diyakini berpotensi menumbuhkan kegiatan ekonomi lainnya (multiple effect). Industri kreatif salah satu yang diuntungkan dari pariwisata di Indonesia. Oleh karena itu penelitian dalam upaya meningkatkan perekonomian sangat diperlukan salah satunya adalah berkaitan dengan manajemen stratejik sumber daya manusia, inovasi dan manajemen pengetahuan sebagai modal untuk
\end{abstract}

meningkatkan sumber daya manusia yang unggul dan berkualitas.

Literatur manajemen stratejik mengakui inovasi sebagai hal yang sangat penting bagi perusahaan untuk menciptakan nilai dan mempertahankan keunggulan kompetitif dalam lingkungan yang semakin kompleks dan cepat berubah (Madhavan dan Grover, 1998; Subramaniam dan Youndt, 2005). Perusahaan dengan inovasi yang lebih besar akan lebih berhasil dalam menanggapi perubahan lingkungan dan dalam mengembangkan kemampuan baru yang memungkinkan mereka untuk 
mencapai kinerja yang lebih baik (Montes et al., 2004). Inisiatif inovasi cenderung sangat bergantung pada pengetahuan, keahlian, dan komitmen karyawan sebagai input utama dalam proses penciptaan nilai (Youndt et al., 1996). Pandangan berbasis pengetahuan menggambarkan perusahaan sebagai gudang pengetahuan dan kompetensi (Grant, 1996; Spender, 1996). Menurut pandangan ini, penelitian sebelumnya mengakui pengetahuan dan kompetensi sumber daya manusia sebagai aset berharga bagi perusahaan karena karakteristik mereka yang spesifik perusahaan, kompleks secara sosial, dan bergantung pada jalur (Collins dan Clark, 2003; Wright et al., 2001; Youndt et al., 1996; Lado dan Wilson, 1994).

Manajemen stratejik sumber daya manusia (SDM) adalah sarana utama di mana perusahaan dapat mempengaruhi dan membentuk keterampilan, sikap, dan perilaku individu untuk melakukan pekerjaan mereka dan dengan demikian mencapai tujuan organisasi (Collins dan Clark, 2003; Martinsons, 1995). Literatur sebelumnya telah memperhatikan hubungan antara manajemen stratejik SDM dan hasil organisasi seperti produktivitas, fleksibilitas, dan kinerja keuangan (misalnya MacDuffie, 1995; Ichniowski et al., 1997; Youndt et al., 1996; Delery dan Doty, 1996; Pfeffer, 1998; Mendelson dan Pillai, 1999; Collins dan Clark, 2003), tetapi pemahamannya perlu diperluas untuk mencakup kinerja inovasi (Laursen dan Foss, 2003). Oleh karena itu, penelitian ini mencoba untuk mengatasi hubungan antara manajemen stratejik SDM dan inovasi perusahaan dari perspektif berbasis pengetahuan.

Inovasi perusahaan dapat memanfaatkan modal manusia untuk mengembangkan keahlian organisasi untuk menciptakan produk dan layanan baru. Namun, keahlian jauh lebih kompleks dan terutama merupakan hasil dari praktik yang disengaja pada tugastugas perwakilan dalam domain (Ericsson dan Charness, 1997). Perusahaan dapat mengidentifikasi dan menggunakan serangkaian manajemen stratejik SDM untuk memperoleh kemauan dan motivasi karyawan untuk terlibat dalam melakukan praktik rumit ini untuk mengembangkan organisasi. keahlian untuk tujuan bisnis seperti kinerja inovasi (Jacobs dan Jones, 1995; Swanson, 1994). Dengan demikian, manajemen stratejik SDM dapat kondusif untuk kegiatan inovatif karena manajemen stratejik SDM memungkinkan perusahaan untuk menemukan dan memanfaatkan pengetahuan dan keahlian dalam organisasi (Scarbrough, 2003). Namun, pengetahuan ada di dalam modal manusia dan perusahaan tidak dapat dengan mudah mentransfer pengetahuan di antara individu-individu di dalam perusahaan (Hansen, 1999; Grant, 1996). Meskipun perusahaan memiliki akses ke pengetahuan, keterampilan dan keahlian karyawan, mungkin perlu memiliki kapasitas yang baik dalam mengelola alat manajemen pengetahuan di tempat untuk memastikan pemanfaatan yang efektif dari sumber daya manusia dalam pengembangan keahlian organisasi untuk inovasi. Manajemen pengetahuan adalah pendekatan untuk menambah atau menciptakan nilai dengan lebih aktif memanfaatkan pengetahuan dan keahlian yang ada dalam pikiran individu (Ruggles, 1998; Scarbrough, 2003). Seperti disebutkan di atas, manajemen pengetahuan dapat mempengaruhi hubungan antara manajemen stratejik sumber daya manusia dan inovasi.

Oleh karena itu, tujuan dari studi ini adalah untuk menguji efek mediasi manajemen pengetahuan antara manajemen stratejik sumber daya manusia dan inovasi berbasis pengetahuan. 


\section{LANDASAN TEORI}

\section{Manajemen stratejik sumber daya manusia}

Manajemen stratejik sumber daya manusia sangat penting untuk keunggulan kompetitif perusahaan dalam ekonomi berbasis pengetahuan yang berubah dengan cepat, beberapa ilmuwan telah memberikan perhatian untuk memeriksa faktor-faktor penentu penerapan manajemen strtaejik sumber daya manusia (misalnya Tannenbaum dan Dupuree-Bruno, 1994) dan pengaruhnya terhadap hasil organisasi, seperti produktivitas dan efisiensi (misalnya MacDuffie, 1995; Ichniowski et al., 1997; Youndt et al., 1996), dan kinerja keuangan (misalnya Delery dan Doty, 1996; Pfeffer, 1998; Mendelson dan Pillai, 1999; Collins dan Clark, 2003).

Penelitian sebelumnya telah memperhatikan dampak manajemen stratejik sumber daya manusia pada hasil organisasi, beberapa studi mengeksplorasi dampak praktik SDM pada manajemen pengetahuan (misalnya Currie dan Kerrin, 2003) dan pada kinerja inovasi (misalnya Laursen dan Foss, 2003). Dengan mengambil perspektif pembelajaran organisasi, Currie dan Kerrin (2003) menggunakan pendekatan studi kasus untuk mengeksplorasi pengaruh "praktik sumber daya manusia strategis", termasuk manajemen kinerja, rekrutmen dan seleksi, interaksi karyawan, dan pengembangan karir, pada peningkatan berbagi pengetahuan dalam sebuah perusahaan. Mereka menyarankan bahwa manajemen stratejik SDM dapat meningkatkan berbagi pengetahuan di perusahaan dengan struktur dan budaya organisasi berbasis fungsional

Manajemen stratejik sumber daya manusia (misalnya Youndt et al., 1996; Collins dan Clark, 2003; Currie dan Kerrin, 2003; Collins dan Clark, 2003), kerja inovatif atau manajemen stratejik sumber daya manusia (mis. Tannenbaum dan Dupuree-Bruno, 1994; MacDuffie, 1995; Ichniowski et al., 1997), manajemen stratejik sumber daya manusia baru (misalnya Laursen dan Foss, 2003), dan karakteristik organisasi era informasi (misalnya Mendelson dan Pillai, 1999). Selain itu, pengukuran manajemen stratejik SDM dalam cara yang berbeda dalam studi sebelumnya untuk mengatasi tujuan penelitian mereka. Penelitian ini bertujuan untuk mengkaji dampak strategis praktik SDM terhadap inovasi melalui efek mediasi manajemen pengetahuan. Studi ini mempertimbangkan langkah-langkah tersebut dalam studi sebelumnya menggunakan konsep manajemen stratejik SDM dan inovatif (misalnya Youndt et al., 1996; Collins dan Clark, 2003; Currie dan Kerrin, 2003; Tannenbaum dan Dupuree-Bruno, 1994; MacDuffie, 1995). karena mereka lebih erat dengan argumen hubungan yang melibatkan manajemen stratejik SDM, manajemen pengetahuan, dan inovasi. Dengan demikian, penelitian ini mengadopsi lima dimensi, termasuk kepegawaian, pelatihan, partisipasi, penilaian kinerja, dan kompensasi, dalam membangun praktik sumber daya manusia yang strategis.

\section{Inovasi}

Pada umumnya peneliti menggunakan konsep-konsep inovasi dan innovasiveness dalam penelitian sebelum tahun 2000 dan menggunakan istilah orientasi inovasi setelah tahun 2000 (Rubina Jabeen, Jamal Mohammed Esmail Alekam, Khaldoun Ahmed Mohammed Aldaoud, Nik Kamariah Nik Mat, Bilal Nayef Ibrahim Zureigat, Alharbi Khalid Nahi, Alaa Muhammad Fadel al Junaidi, 2013) sesuai dengan pendapat Eris dan Ozmen (2012), inovasi adalah kegiatan menantang dan menghadapi ketidakpastian yang ada dan 
versi yang diperbaharui orientasi inovasi merupakan pengembangan produk saat ini dan proses produksi, serta inovasi radikal yang pada dasarnya pengembangan atau penerapan ide-ide baru dan teknologi baru.

Inovasi adalah gagasan dari keterbukaan terhadap ide-ide baru sebagai aspek budaya perusahaan, inovasi adalah suatu ide, gagasan, praktek atau objek/benda yang disadari dan diterima sebagai suatu hal yang baru oleh seseorang atau kelompok untuk diadopsi. (Robbins, 2005) mendefinisikan inovasi sebagai suatu gagasan baru yang diterapkan untuk memprakarsai atau memperbaiki suatu produk atau proses dan jasa. Robbins (2005) mendefinisikan inovasi adalah proses mengubah ide-ide kreatif menjadi produk atau metode kerja yang berguna. Sedangkan Kasali (2010) mengatakan bahwa inovasi adalah kemampuan untuk melihat segala sesuatu dengan cara yang baru dan kadang diluar kebiasaan (out of the box thinking). Dengan demikian inovasi adalah ide atau gagasan baru untuk suatu perbaikan produk atau jasa. Inovasi terjadi karena adanya pelatihan dan pembelajaran dengan invensi dan komersialisasi. Dengan kata lain inovasi merupakan organisasi yang mengintegrasikan teknologi, organisasi dan perubahan pasar untuk tetap bisa eksis dan berkembang.

Penelitian Lee dan Tsai (2005); Eshlaghy dan Maatofi (2011); (Suliyanto \& Rahab, 2012); Pratono et al., (2013), mengemukakan bahwa inovasi berpengaruh terhadap kinerja perusahaan. Inovasi dapat diukur dengan sering tidaknya perusahaan mengenalkan inovasi produk, inovasi proses, inovasi pemasaran dan inovasi manajemen (Serna, Martinez dan Guzman, 2013). Jadi inovasi adalah suatu ide, gagasan yang disadari serta diterima oleh seseorang atau kelompok untuk perbaikan pada produk, proses, pemasaran dan manajemen.
Indikator dari inovasi adalah menurut Serna, Martinez dan Guzman (2013) adalah: 1). Inovasi produk: pengenalan produk barang atau jasa yang benar benar baru diperkenalkan pada konsumen sebagai pembaharuan dari produk yang telah ada atau telah melalui peningkatan yang signifikan terkait karakteristik atau tujuan penggunaan produk tersebut. 2). Inovasi proses: penerapan metode produksi atau pengiriman yang benar-benar baru atau telah melalui peningkatan yang signifikan. 3). Inovasi pemasaran: penerapan metode pemasaran yang baru atau peningkatan signifikan pada pengemasan atau desain produk, penempatan produk, promosi produk dan harga dengan tujuan untuk meningkatkan penjualan, memenuhi kebutuhan konsumen, membuka pasar baru, menempatkan produk perusahaan dalam pasar. 4). Inovasi manajemen /organisasi: penerapan metode organisasi baru pada praktik bisnis, organisasi tempat kerja, hubungan eksternal perusahaan. (Serna, Martinez dan Guzman, 2013) Menurut Barringer dan Ireland (2013) inovasi adalah proses penciptaan sesuatu yang baru. Dalam duania bisnis inovasi sebagai suatu disiplin belum mencapai tahap perkembangan yang diharapkan dalam memenuhi kebutuhan tertentu yang mendesak (Ma'atoofi dan Tajeddini, 2013)

Inovasi selalu terkait dengan beberapa praktik yang nilainya membumi yaitu tentang membuat alat, produk atau proses yang baru, melahirkan sesuatu yang baru yang memungkinknan manusia untuk mencapai sesuatu yang tidak mampu dicapai sebelumnya (De Bes dan Kotler, 201I) sesuai dengan pendapat Tidd dan Bessant (2009) inovasi bukan mengenai munculnya produk baru atau yang lebih baik tetapi mengenai pemecahan masalah yang harus muncul pertama kali (Bleeker, 2011), inovasi 
adalah keberhasilan sosial dan ekonomi karena ditemukannya cara-cara baru atau kombinasi baru dari cara-cara lama dalam menstransformasikan input menjasi output sedemikian rupa sehingga berhasil menciptakan perubahan besar atau perubahan drastis dalam hubungan antara nilai guna dan manfaat (yang dipersepsikan oleh konsumen atau pengguna) dan nilai moneter atau harga (Fontana, 2011), menurut Fischer (2013) inovasi tidak saja berarti kebaruan atau sesuatu yang barang dan/jasa baru atau system produksi baru atau cara memasarkan hal yang baru (AvdelidouFischer, 2013).

Proses inovasi didorong oleh kebutuhan untuk memahami bagaimana sesuatu bekerja untuk menumbuhkan pendapatan, mengurangi biaya atau meningkatkan produktivitas, untuk memecahkan masalah pelanggan, menjaga hidup sehat dan aman. (Locatelli dan Reigner, 2007) terdapat lima nilai inti dari inovasi yaitu questioning, risk taking, openness, patience dan trust. Dimensi inovasi adalah inovasi produk atau perubahan-perubahan dalam segala hal (produk/jasa), inovasi proses adalah perubahan-perubahan dalam cara-cara yang diciptakan dan disampaikan, inovasi posisi adalah perubahan- perubahan yang mendasari mental model yang menggambakan hal yang dilakukan perusahaan (Tidd dan Bessant, 2009; Bleeker, 2011).

\section{Manajemen pengetahuan}

Teori resource based view of firm (RBV) menerangkan bahwa sumber daya strategis bila memenuhi beberapa kriteria yaitu langka, berharga, sulit ditiru dan sulit digantikan, teori knowledge based view of the firm (KBV) mendukung pandangan bahwa pengetahuan merupakan sumber daya yang paling strategis karena memenuhi kriteria tersebut. Organisasi atau perusahaan yang unggul yang mampu mengelola pengetahuan untuk melakukan inovasi di masa yang akan datang, sejalan dengan pernyataan Senge (1995) tentang organisasi pembelajar (learning organization) yaitu pihak yang melakukan kegiatan belajar adalah sumber daya manusia pada suatu organisasi atau perusahaan (Dalkir, 2005).

Manajemen pengetahuan adalah informasi yang terorganisisasi sehingga dapat diterapkan untuk memecahkan, Turban, et al (2004) yang mengatakan bahwa pengetahuan merupakan informasi yang telah dianalisis dan diorganisasikan sehingga dapat dimengerti dan digunakan untuk memecahkan masalah dan mengambil keputusan. Untuk memperoleh manfaat optimal dari pengetahuan yang dimiliki oleh sumber daya manusia dalam suatu organisasi atau perusahaan maka dibutuhkan pengelolaam pengetahuan (Natek, 2016).

Manajemen pengetahuan menurut Swan, et al (2005) yaitu setiap proses atau praktek untuk menciptakan, memperoleh, menangkat, berbagi dan menggunakan pengetahuan dimanapun berada yang bermanfaat untuk meningkatkan pembelajaran dan kinerja dalam organisasi atau perusahaan. Manajemen pengatahuan dilakukan dengan mengidentifikasikan pengetahuan yang dimiliki oleh seluruh sumber daya manusia dan memanfaatkannya sebagai keunggulan kompetitif. Terdapat delapan proses pengelolaan pengelolaan pengetahuan yaitu: 1). Proses penetapan sasaran (knowledge goal). 2). Proses identifikasi pengetahuan. 3). Proses akuisisi pengetahuan. 4). Proses pengembangan pengetahuan. 5). Proses berbagi dan distribuasi pengetahuan. 6). Proses pemeliharaan dan penyimpanan pengetahuan (knowledge retention) dan 7). Proses evaluasi dan pengukuran pengetahuan (knowledge assessment). 
Kemudian disederhanakan oleh McElroy (2002) menjadi tiga proses yaitu proses akuisisi pengetahuan, proses berbagi pengetahuan dan proses pemanfaatan pengetahuan. (Sharokhi, Mobarakabadi, dan Slambolchi, 2017).

Wigg (2005) dalam menentukan berbagai tingkat proses internasionalisasi manajemen pengetahuan. Rentang tingkat internalisasi dikelompokkan ke dalam mode yang berbeda seperti awam (notice), pemula (beginner), kompeten (competent), ahli (expert), master (master) (Dalkir, 2005).

Wigg (2005) dalam model kerangka pemikiran manajemen pengetahuannya dikembangkan oleh Nonaka disebut dengan konversi pengetahuan (knowledge conversion). Model konversi pengetahuan ini yang mendorong penciptaan pengetahuan yaitu sosialisasi, eksternalisasi, internalisasi dan kombinasi. Konversi ini didasarkan pada dikotomi antara pengetahuan tacit dan explicit (Dalkir, 2005)

Pengetahuan tacit mengacu pada pengetahuan yang tidak dapat dengan mudah diungkapkan secara verbal dan diartikulasikan, sedangkan pengatahuan explicit mengacu pada pengetahuan yang dapat dengan mudah diungkapkan secara verbal dalam bahasa yang formal sistematis, Konversi didasarkan pada pengakuan perbedaan antara pengetahuan individu dan pengetahuan kolektif, kemudian model kerangka kerja ini dikembangkan oleh Nonaka \& Takeuchi (2000) (Nonaka dan Takeuchi, 2000) menjadi empat mode konversi pengetahuan (Natek, 2016).

Empat model konversi pengetahuan diidentifikasikan tacit terhadap tacit (sosialisasi), tacit terhadap explicit (eksternalisasi), explicit terhadap explicit (kombinasi) dan explicit terhadap tacit (internalisasi). Setelah mengalami proses internalisasi kemudian pengetahuanakan masuk dalam metafora "spiral" pendiltaan pengetahuan yang disebut model SECI. Sosialisasi adalah proses menciptakan pengetahuan dengan mengubah pengetahuan tacit dari satu entitas (individu, kelompok, atau organisasi) ke entitas lain. Kombinasi adalah proses menciptakan pengetahuan explicit baru dari pengetahuan explicit yang ada. Konversi pengetahuan tacit ke dalam pengetahuan explicit disebut eksternalisasi. Konversi pengetahuan explicit ke dalam pengetahuan tacit disebut internalisasi. Pengetahuan organisasi atau perusahaan diciptakan oleh interaksi di antara keempat proses konversi ini dan melalui transfer pengetahuan dari individu ke kelompok ke tingkat organisasi/ perusahaan.

\section{Manajemen stratejik sumber daya manusia dan inovasi}

Pandangan berbasis pengetahuan menyangkut pengetahuan sebagai sumber daya yang berharga dari perusahaan (Grant, 1996; Spender, 1996). Pengetahuan yang tertanam dalam modal manusia memungkinkan perusahaan untuk meningkatkan kompetensi khusus dan menemukan peluang inovasi (Hansen, 1999; Grant, 1996; Wright et al., 2001). Ketika perusahaan mengembangkan produk baru dan meningkatkan proses manajemen, mereka membutuhkan motivasi dan kemampuan modal manusia untuk menghasilkan ideide kreatif, mengembangkan pendekatan inovatif, dan menggunakan peluang baru (Scarbrough, 2003). Fungsi manajemen sumber daya manusia dapat mempengaruhi dan memodifikasi sikap, kapasitas, dan perilaku karyawan untuk mencapai tujuan organisasi (Collins dan Clark, 2003; Martinsons, 1995) dan memainkan peran penting dalam memelihara kondisi yang diperlukan untuk mengkatalisasi dan menyalurkan individu menuju pengembangan kegiatan inovasi (Scarbrough, 2003; Laursen dan Foss, 2003; Michie dan Sheehan, 1999). Perusahaan dapat menggunakan beberapa 
praktik SDM strategis, seperti penempatan staf, pelatihan, partisipasi, penilaian kinerja, dan kompensasi, sebagai sarana untuk memotivasi komitmen karyawan dan membuat mereka terlibat dalam pemikiran kreatif dan inovasi (Damanpour, 1991; Laursen dan Foss, 2003). Dengan demikian, penelitian ini berpendapat bahwa manajemen stratejik SDM akan memainkan peran penting dalam mempengaruhi inovasi.

Ketika

perusahaan mengembangkan aktivitas inovasi, mereka menghadapi ketidakpastian dan variabilitas yang relatif lebih besar dalam proses inovasi (Atuahene-Gima, 1996), dan mereka membutuhkan karyawan kreatif yang fleksibel, berani mengambil risiko, dan toleran terhadap ketidakpastian dan ambiguitas (Madsen dan Ulhøi, 2005). Oleh karena itu, perusahaan harus lebih menekankan pada karakteristik ini dalam tindakan penempatan staf. Ketika perusahaan menggunakan kemampuan kreatif dan karakteristik inovatif sebagai kriteria perekrutan dan seleksi, karyawan mereka cenderung menelurkan keragaman ide dan berkomitmen untuk lebih banyak perilaku inovasi (Brockbank, 1999; Atuahene-Gima,1996). Melalui staf yang efektif, karyawan menjadi sumber penting dari ide-ide baru dalam proses inovatif perusahaan. Perusahaan dapat memperoleh keterlibatan dan partisipasi karyawan dengan memberikan mereka untuk memecahkan masalah dan untuk berpartisipasi dalam pengambilan keputusan yang mempengaruhi pekerjaan mereka (Damanpour, 1991; Glynn, 1996). Tingkat partisipasi yang tinggi akan menciptakan kondisi untuk mendorong karyawan untuk membawa ide-ide baru dan bertukar pengetahuan dalam proses inovasi yang sedang berlangsung dan, pada gilirannya, meningkatkan hasil yang inovatif
(Jiménez-Jiménez dan Sanz-Valle, 2005; Tsai, 2002).

Berdasarkan pada penelitian yang sudah dilakukan menunjukkan bahwa perusahaan dapat menggunakan manajemen stratejik SDM untuk mempengaruhi perilaku dan harapan karyawan, dan menambah nilai lebih besar dalam mengembangkan inovasi. Melalui manajemen strtatejik SDM yang efektif dalam hal kepegawaian, pelatihan, partisipasi, penilaian kinerja, dan kompensasi, perusahaan akan meningkatkan kemampuan mereka dalam memperkenalkan produk, layanan, dan sistem manajemen baru, dan kemudian mencapai hasil inovasi yang lebih baik, Maka hipotesisnya sebagai berikut: Hipotesis 1. Manajemen stratejik sumber daya manusia berhubungan positif dengan inovasi.

\section{Manajemen stratejik sumber daya manusia dan manajemen pengetahuan} Modal manusia, dengan pengetahuan, keahlian, dan keterampilan mereka, merupakan sumber daya yang berharga bagi perusahaan (Lado dan Wilson, 1994; Delery dan Doty, 1996; Wright et al., 2001; Collins dan Clark, 2003).

Organisasi yang secara efektif mengelola dan memanfaatkan pengetahuan dan keahlian yang tertanam dalam pikiran individu akan mampu menciptakan nilai lebih dan mencapai keunggulan kompetitif yang unggul (Ruggles, 1998; Scarbrough, 2003). Namun, karyawan sering tidak mau atau tidak dapat berbagi pengetahuan dan keahlian mereka dengan orang lain karena kepentingan diri sendiri dan kurangnya kepercayaan (Currie dan Kerrin, 2003; Hayes dan Walsham, 2000; Mueller dan Dyerson, 1999; Davenport dan Prusak, 1998). Oleh karena itu, penting bagi perusahaan untuk memanfaatkan keterlibatan dan 
partisipasi karyawan melalui manajemen pengetahuan.

Manajemen stratejik sumber daya manusia adalah pendekatan utama untuk memperoleh dan memperkuat pengetahuan dan keahlian karyawan yang dibutuhkan perusahaan (Martinsons, 1995; Youndt et al., 1996; Collins dan Clark, 2003). Karena orang adalah pembawa banyak pengetahuan dan keahlian khusus organisasi, perusahaan mungkin yang terbaik untuk memanfaatkan manajemen stratejik SDM untuk mengelola pengetahuan dan keahlian (Scarbrough dan Carter, 2000; Lave dan Wenger, 1991). Beberapa manajemen stratejik SDM seperti penempatan staf, pelatihan, partisipasi, evaluasi kinerja, dan kompensasi insentif, terkait dengan peningkatan komitmen, penurunan pergantian, dan peningkatan kinerja melalui dampaknya terhadap pengembangan dan motivasi karyawan (Huselid, 1995; Becker dan Gerhart, 1996).; Guthrie, 2001). Perusahaan dapat menggunakan manajemen SDM ini untuk memberi karyawan keterampilan, sumber daya, dan kebijaksanaan yang mereka butuhkan untuk mengembangkan manajemen pengetahuan. Dengan demikian, penelitian ini berpendapat bahwa manajemen stratejik SDM dalah elemen kunci yang memungkinkan bagi perusahaan untuk meningkatkan kapasitas mereka dalam menyebarkan dan memfasilitasi alat dan aktivitas manajemen pengetahuan.

Sistem kepegawaian yang efektif dapat membantu perusahaan dalam memilih dan mengalokasikan tenaga kerja yang kompeten dan berkualitas untuk melakukan tugas-tugas yang diperlukan. Memperoleh karyawan dengan pengetahuan dan keahlian tertentu sangat penting bagi perusahaan untuk mengoperasikan alat dan aktivitas manajemen pengetahuan. Karyawan yang baru direkrut kemungkinan akan melakukan sharing knowledge secara efektif jika mereka mampu mengambil perspektif yang lebih luas dan sikap yang tepat (Currie dan Kerrin, 2003). Selain itu, penting juga bagi perusahaan untuk memilih karyawan yang dapat berintegrasi secara efektif untuk pengembangan kapasitas manajemen pengetahuan. Pemilihan individu dengan keterampilan dan sikap yang tepat untuk melakukan tugas memungkinkan perusahaan untuk mengintegrasikan pengetahuan dari berbagai sumber dan merangsang generasi ide yang inovatif (Martinsons, 1995; Scarbrough, 2003). Selain itu, pelatihan karyawan juga kemungkinan akan mempengaruhi pengembangan kapasitas manajemen pengetahuan.

Pengembangan profesional berkelanjutan sangat penting bagi pekerja pengetahuan. Perusahaan perlu menawarkan kesempatan pelatihan internal dan eksternal untuk mengembangkan dan memelihara pengetahuan dan keahlian karyawan yang dibutuhkan (Jaw dan Liu, 2003; Brockbank, 1999; Nonaka dan Takeuchi, 1995). Paparan program pelatihan yang beragam dapat mendorong karyawan untuk mempelajari pengetahuan dan keahlian baru, memperluas wawasan mereka, dan membekali mereka dengan pikiran dan keterampilan yang inovatif (Nonaka dan Takeuchi, 1995). Program pelatihan semacam itu akan merangsang karyawan untuk berbagi keahlian dan pengalaman mereka, memperoleh pengetahuan baru, dan memanfaatkan apa yang mereka pelajari selanjutnya dalam pekerjaan. Dengan demikian program pelatihan sangat penting bagi karyawan dalam proses manajemen pengetahuan (Argote et al., 2003; Von Krogh, 1998).

Partisipasi manajemen stratejik sumber daya manusia lainnya, dapat menarik karyawan untuk terlibat secara positif dan berkontribusi dalam pengetahuan kegiatan manajemen dan pembelajaran. Individu yang memiliki 
keterampilan, keahlian, dan tanggung jawab kerja yang lebih luas harus memberikan otonomi dan pengaturan diri yang lebih besar untuk melakukan pekerjaan mereka (Nonaka dan Takeuchi, 1995). Pemberian lebih banyak keleluasaan dan partisipasi dalam pengambilan keputusan dapat meningkatkan keterlibatan, kesadaran, dan komitmen karyawan (Damanpour, 1991; Glynn, 1996). Jika karyawan memiliki lebih banyak kesempatan untuk memberikan masukan dan menentukan tindakan yang diperlukan, mereka dapat meningkatkan keragaman dan kekayaan pertukaran pengetahuan dan membawa lebih banyak ide baru (Andrews dan Kacmar, 2001; Grant, 1996), sehingga memfasilitasi penemuan dan pemanfaatan pengetahuan. menyebarkan pengetahuan dan keahlian dalam organisasi.

Manajemen stratejik sumber daya manusia sangat membantu untuk memotivasi kesediaan karyawan untuk memperoleh, berbagi, dan menerapkan pengetahuan dalam organisasi. Manajemen stratejik SDM yang tepat dapat mendukung dan mempromosikan pengembangan lingkungan organisasi yang kondusif untuk kegiatan manajemen pengetahuan. Dengan demikian, manajemen stratejik sumber dauya manusia akan mempengaruhi kapasitas manajemen pengetahuan secara positif. Berdasarkan penelitian sebelumnya maka hipotesis 2 sebagai berikut: Hipotesis 2. Manajemen stratejik sumber daya manusia berhubungan positif dengan manajemen pengetahuan.

\section{Manajemen pengetahuan dan inovasi}

Inovasi organisasi, yang memerlukan pengembangan produk atau layanan baru serta sistem administrasi baru, muncul sebagai sumber penting keunggulan kompetitif yang berkelanjutan (Damanpour, 1991; Hurley dan Hult, 1998). Proses inovasi melibatkan perolehan, penyebaran, dan penggunaan pengetahuan baru dan yang sudah ada (Damanpour, 1991; Moorman dan Miner, 1998). Inovasi organisasi terkait erat dengan kemampuannya untuk memanfaatkan sumber daya pengetahuannya (Subramaniam dan Youndt, 2005). Manajemen pengetahuan adalah pendekatan yang lebih aktif memanfaatkan pengetahuan dan keahlian untuk menciptakan nilai dan meningkatkan efektivitas organisasi (Gold et al., 2001; Ruggles, 1998; Scarbrough, 2003). Perusahaan yang menunjukkan tingkat kapasitas manajemen pengetahuan yang lebih besar mengalami efek pembelajaran yang dapat meningkatkan kemampuan mereka dalam mengurangi redundansi, merespons dengan cepat terhadap perubahan, dan mengembangkan ide-ide kreatif dan inovasi (Scarbrough, 2003; Gold et al., 2001). Manajemen pengetahuan yang efektif memfasilitasi komunikasi dan pertukaran pengetahuan yang diperlukan dalam proses inovasi, dan selanjutnya meningkatkan kinerja inovasi melalui pengembangan wawasan dan kemampuan baru (Madhavan dan Grover, 1998; Nonaka dan Takeuchi, 1995; Von Krogh, 1998). Oleh karena itu, kapasitas manajemen pengetahuan memainkan peran penting dalam mendukung dan mendorong inovasi. Karena mengelola pengetahuan dalam proses inovasi itu kompleks, studi ini berfokus pada mekanisme yang digunakan organisasi untuk memperoleh, berbagi, dan menerapkan pengetahuan baru atau yang ditingkatkan.

Pengetahuan yang baru diperoleh berinteraksi dengan pengetahuan yang ada dapat memodifikasi stok pengetahuan organisasi (Nonaka dan Takeuchi, 1995; Gold et al., 2001) dan meningkatkan luas dan kedalaman pengetahuan yang tersedia bagi perusahaan, sehingga meningkatkan potensi hasil inovatif baru (Galunic dan Rodan, 1998; Li dan Calantone, 1998; Yli-Renko et al., 2001). 
Pandangan berbasis pengetahuan menunjukkan bahwa kegiatan akuisisi pengetahuan akan meningkatkan kemampuan perusahaan untuk secara efisien melakukan perannya (Grant, 1996). Perusahaan dengan kemampuan yang baik untuk memperoleh pengetahuan eksternal dan internal akan mengurangi ketidakpastian dan mencapai lebih banyak kekhasan administratif dan teknologi (Li dan Calantone, 1998; Sarin dan McDermott, 2003; Yli-Renko et al., 2001). Dengan demikian, penelitian ini berpendapat bahwa akuisisi pengetahuan memiliki hubungan positif dengan kinerja inovasi.

Penelitian

menunjukkan

pengetahuan

peningkatan

(misalnya Kogut dan Zander, 1992;

Henderson dan Cockburn, 1994;

Szulanski, 1996; Tsai dan Ghoshal, 1998; Dyer dan Nobeoka, 2000; Tsai, 2001). Secara khusus, para sarjana telah berpendapat sebelumnya bahwa berbagi pengetahuan menyiratkan kombinasi baru dari pengetahuan yang sebelumnya telah ada secara terpisah, yang mungkin akan menghasilkan perbaikan proses atau produk baru (Schumpeter, 1912/1934; Kogut dan Zander, 1992; Tsai dan Ghoshal, 1998). Karena pengetahuan ada dalam individu yang berbeda dan tingkat organisasi yang berbeda, anggota organisasi perlu membaginya untuk membangun rutinitas dan model mental baru (Galunic dan Rodan, 1998; Nonaka dan Takeuchi, 1995). Juga, ketika individu bersedia untuk berbagi dan bertukar pengetahuan, mereka dapat menghasilkan pembelajaran kolektif dan manfaat sinergis dari proses pertukaran pengetahuan dan sumber daya (Nonaka dan Takeuchi, 1995; Nonaka dan Konno, 1998). Inovasi muncul ketika anggota organisasi berbagi keahlian mereka dan mengubahnya menjadi bentuk eksplisit produk atau jasa (Von Krogh, 1998;
Nonaka dan Konno, 1998). Karenanya, perusahaan yang mampu secara efektif berbagi pengetahuan di antara anggota cenderung lebih inovatif.

Dari pandangan berbasis pengetahuan, nilai pengetahuan individu dan organisasi terletak terutama pada penerapannya karena kelekatan dan tacitness pengetahuan (Grant, 1996; Spender, 1996). Pengembangan dan inovasi produk baru memerlukan penerapan dan kombinasi masukan pengetahuan khusus dari berbagai bidang (Yli-Renko et al., 2001). Aplikasi pengetahuan yang lebih dalam memungkinkan perusahaan secara terusmenerus menerjemahkan keahlian organisasi mereka ke dalam produk yang diwujudkan (Weisberg, 2006; Sarin dan McDermott, 2003). Dengan menerapkan pengetahuan secara efektif, individu mungkin membuat lebih sedikit kesalahan atau meningkatkan efisiensi mereka dan mengurangi redundansi (Grant, 1996; Gold et al., 2001). Organisasi kemudian pada akhirnya dapat mempercepat pengembangan produk baru dan menciptakan teknologi pemrosesan produksi dan sistem administrasi yang lebih inovatif (Sarin dan McDermott, 2003).

Penelitian sebelumnya menunjukkan manajemen pengetahuan dalam hal akuisisi, berbagi, dan aplikasi memberikan kontribusi positif terhadap inovasi perusahaan. Melalui manajemen pengetahuan yang efektif, perusahaan akan dapat mengubah pengetahuan menjadi produk, layanan, dan proses yang inovatif, dan dengan demikian menghasilkan hasil inovasi yang lebih baik. Berdasarkan beberapa pendapat tersebut makan hipotesis 3 sebagai berikut: Hipotesis 3. Manajemen pengetahuan berhubungan positif dengan inovasi.

\section{Efek mediasi dari manajemen pengetahuan}


Hipotesis sebelumnya menghubungkan hubungan antara manajemen stratejik sumber daya manusia manajemen pengetahuan, dan kinerja inovasi. Secara implisit, diskusi menunjukkan bahwa manajemen stratejik sumber daya manusia mempengaruhi inovasi perusahaan melalui manajemen pengetahuan. Artinya, perusahaan dapat menggunakan manajemen stratejik sumber daya manusia untuk menumbuhkan tingkat pengetahuan, berbagi, dan aplikasi, yang, pada gilirannya, mempromosikan kecenderungan karyawan untuk berinovasi dan meningkatkan inovasi mereka. Dengan demikian, penelitian ini berpendapat bahwa manajemen pengetahuan memainkan peran mediasi dalam hubungan antara variabel independen dari manajemen stratejik sumber daya manusia dan variabel dependen inovasi. Mengacu pada pendapat tersebut maka hipotesis 4 sebagai berikut: Hipotesis 4. Manajemen pengetahuan memediasi hubungan antara manajemen stratejik sumber daya manusia dan inovasi.

\section{METODE PENELITIAN}

\section{Pengumpulan data dan sampel}

Penelitian ini menggunakan pendekatan survei kuesioner untuk mengumpulkan data untuk menguji validitas model dan hipotesis penelitian. Variabel dalam kuesioner meliputi latar belakang informasi, praktik stratejik sumber daya manusia, manajemen pengetahuan, dan inovasi. Semua variabel independen dan dependen memerlukan tujuh poin tanggapan dengan skala Likert mulai dari "sangat tidak setuju" hingga "sangat setuju". Sampel penelitian ini adalah perusahaan industri kreatif yang ada di Indonesia. Penelitian ini menggunakan metode simple random sampling untuk memilih 150 perusahaan industri kreatif.

\section{HASIL PENELITIAN DAN PEMBAHASAN}

\section{Hasil Penelitian}

\section{Validitas and reliabilitas test}

Hasil tes validitas dan reliabilitas variabel penelitian sebagai berikut pada tabel dibawah:

Tabel 1: Hasil Validitas Test Instrumen Penelitian

\begin{tabular}{lllll}
\hline Variabel & $\begin{array}{l}\text { Coefficient } \\
\text { Correlatin }\end{array}$ & Significamce & Cut Of Value & Information \\
\hline Manajemen stratejik SDM & 0.838 & 0.000 & 0.05 & Valid \\
Manajemen pengetahuan & 0.819 & 0.000 & 0.05 & Valid \\
Inovasi & 0,827 & 0.000 & 0.05 & Valid \\
\hline
\end{tabular}

Sumber : Data Primer 2020

Tabel 2: Hasil Reliabilitas Test Instrumen Penelitian

\begin{tabular}{lcc}
\hline Variabel & $\begin{array}{c}\text { Reliability statistics } \\
\text { Cronbach's alpha }\end{array}$ & Keterangan \\
\hline Manajemen stratejik SDM & 0,827 & Reliabel \\
Manajemen Pengetahuan & 0,836 & Reliabel \\
Inovasi & 0,829 & Reliabel \\
\hline
\end{tabular}

Sumber : Data Primer 2020

Berdasarkan tabel 1 dan 2, semua instrument penelitian layak digunakan karena memiliki tingkat validitas dan reliabilitas yang tinggi.

This work is licensed under a Creative Commons Attribution-NonCommercial-ShareAlike 4.0 International License. Ciptaan disebarluaskan di bawah Lisensi Creative Commons Atribusi-BerbagiSerupa 4.0 Internasional. 


\section{Analasis deskriptif}

Deskripsi analisis menggunakan index value, skala yang digunakan 1 sampai 7 hasil penelitian dapat dilihat pada table berikut:

Tabel 3: Variabel manajemen stratejik sumber daya manusia berdasarkan pilihan responden

\begin{tabular}{lcccccccc}
\hline $\begin{array}{l}\text { Indikator } \\
\text { Variabel }\end{array}$ & 1 & 2 & 3 & 4 & 5 & 6 & 7 & index \\
\hline Kepegawaian & 14.8 & 23.6 & 16.5 & 14.3 & 11.5 & 12.1 & 7.1 & 49.8 \\
Pelatihan & 8.2 & 23.4 & 18.7 & 18.1 & 8.8 & 13.2 & 9.3 & 53.2 \\
Partisipasi & 12.6 & 16.5 & 24.7 & 18.1 & 13.2 & 3.3 & 11.5 & 51.2 \\
Kinerja & 2.7 & 3.3 & 18.1 & 21.4 & 13.7 & 22.0 & 18.7 & 68.7 \\
Konpensai & 8.3 & 22,3 & 18.7 & 18.1 & 9.8 & 13.1 & 11.7 & 51.2 \\
$\quad$ Rata - rata & & & & & & & & 54.8 \\
\hline
\end{tabular}

Tabel 4: Variabel Manajemen Pengetahuan berdasarkan pilihan responden

\begin{tabular}{lcccccccc}
\hline $\begin{array}{c}\text { Indikator } \\
\text { Variabel }\end{array}$ & 1 & 2 & 3 & 4 & 5 & 6 & 7 & Index \\
\hline Eksternaslisasi & 13.7 & 11.5 & 22.0 & 15.4 & 24.7 & 9.3 & 3.3 & 52.4 \\
Kombinasi & 6.6 & 13.7 & 24.2 & 18.1 & 21.4 & 8.8 & 7.1 & 55.5 \\
Sosialisasi & 14.8 & 13.2 & 16.5 & 18.1 & 13.8 & 14.3 & 8.3 & 54.3 \\
Internalisasi & 1.4 .8 & 13.2 & 16.5 & 18.1 & 13.8 & 14.3 & 8.3 & 54.1 \\
$\quad$ Rata-rata & & & & & & & & 54,1 \\
\hline
\end{tabular}

Sumber : Data Primer 2020

Tabel 5: Variabel Inovasi berdasarkan pilihan responden

\begin{tabular}{lcccccccc}
\hline \multicolumn{1}{c}{ Indikator Variabel } & 1 & 2 & 3 & 4 & 5 & 6 & 7 & Index \\
\hline Inovasi Produk & 14.8 & 23.6 & 16.5 & 14.3 & 11.5 & 12.1 & 7.1 & 49.8 \\
Inovasi Proses & 10.4 & 17.6 & 14.3 & 19.8 & 18.1 & 9.3 & 10.4 & 55.3 \\
Inovasi Pemasaran & 20.8 & 16.5 & 12.6 & 13,7 & 12.6 & 9.9 & 13.7 & 52.1 \\
Inovasi & 1.4 .8 & 13.2 & 16.5 & 18.1 & 13.8 & 14.3 & 8.3 & 52.1 \\
Manajemen/organisasi & & & & & & & & \\
$\quad$ Rata-rata & & & & & & & & 52,3 \\
\hline \multicolumn{1}{l}{ Data Primer 2020 } & & & & & & & &
\end{tabular}

\section{Analisis Jalur}

Hasil analisis uji hipotesis sebagai berikut:

Tabel 6: Hasil Analisis Hipotesis

\begin{tabular}{|c|c|c|c|}
\hline Variabel & Estimasi & t Stat & Signifikansi \\
\hline Manajemen stratejik SDM-Inovasi & 0.658 & 7.612 & $<0.05$ \\
\hline $\begin{array}{l}\text { Manajemen Stratejik SDM - } \\
\text { Manajemen Pengetahuan }\end{array}$ & 0.077 & 1.988 & $<0.05$ \\
\hline Manajemen Pengetahuan - Inovasi & 0.299 & 3,968 & $<0.05$ \\
\hline
\end{tabular}

This work is licensed under a Creative Commons Attribution-NonCommercial-ShareAlike 4.0 International License 


\section{Sumber : Data Primer 2020}

Pengujian keempat hipotesis yang diajukan dalam penelitian ini dilakukan dengan menganalisis nilai Critical Ratio (CR) dan probabilitas dari suatu hubungan kausalitas.

Berdasarkan Tabel yang di sajikan, pengujian hipotesis dapat dijelaskan sebagai berikut:

\section{Pengujian Hipotesis 1}

H1: Manajemen stratejik sumber daya manusia berpengaruh positif dan siginifikan terhadap inovasi. Parameter estimasi untuk pengujian pengaruh manajemen stratejik sumber daya manusia terhadap inovasi menunjukkan nilai CR sebesar 7,612 dengan probabilitas sebesar 0,000 . Oleh karena nilai probabilitas $<0,05$ maka dapat disimpulkan bahwa manajemen stratejik sumber daya manusia terbukti secara positif dan signifikan berpengaruh terhadap inovasi. Hasil penelitian membuktikan hipotesis 1 teruji.

\section{Pengujian Hipotesis 2}

$\mathrm{H} 2$ : Manajemen stratejik sumber daya manusia positif dan signifikan terhadap manajemen pengetahuan. Parameter estimasi untuk pengujian pengaruh manajemen stratejik sumber daya manusia terhadap manajemen pengetahuan menunjukkan nilai $\mathrm{CR}$ sebesar 1,988 dengan probabilitas sebesar $<0,05$. Oleh karena nilai probabilitas < 0,05 maka dapat disimpulkan bahwa variabel manajemen stratejik sumber daya manusia secara positif dan signifikan berpengaruh terhadap inovasi. Hasil penelitian membuktikan hipotesis 2 teruji.

\section{Pengujian Hipotesis 3}

H3: Manajemen pengetahuan berpengaruh positif dan signifikan terhadap inovasi. Parameter estimasi untuk pengujian pengaruh manajemen pengetahuan terhadap inovasi menunjukkan nilai $\mathrm{CR}$ sebesar 3,968 dengan probabilitas sebesar 0,000 . Oleh karena nilai probabilitas $<0,05$ maka dapat disimpulkan bahwa variabel manajemen pengetahuan erbukti secara berpengaruh positif dan signifikan terhadap inovasi. Hasil penelitian membuktikan. Hasil penelitian membuktikan hipotesis 3 teruji.

\section{Pengujian Hipotesis 4}

H4: Manajemen stratejik sumber daya manusia berpengaruh positif dan signifikan terhadap inovasi melalui manajemen pengetahuan. Parameter estimasi untuk pengujian manajemen stratejik sumber daya manusia terhadap inovasi yang dimediasi oleh manajemen pengetahuan menunjukkan nilai CR sebesar 7.612 dan 3,968 dengan probabilitas sebesar 0,000 . Oleh karena nilai probabilitas $<0,05$ maka dapat disimpulkan bahwa terbukti variabel manajemen pengetahuan memediasi antara variabel manajemen stratejik sumber daya manusia terhadap inovasi. Hasil penelitian membuktikan hipotesis 4 teruji.

Temuan satu menunjukkan bahwa perusahaan akan mencapai tingkat inovasi yang lebih tinggi jika mereka memiliki staf, partisipasi, penilaian kinerja, dan praktik kompensasi yang berkembang dengan baik. Dengan demikian, hasilnya cukup mendukung Hipotesis 1, yang menyatakan bahwa manajemen stratejik sumber daya manusia berhubungan positif dengan inovasi.

Temuan kedua menunjukkan bahwa perusahaan akan mencapai tingkat kapasitas manajemen pengetahuan yang lebih tinggi jika mereka berusaha menarik dan memilih "pekerja premium", berinvestasi lebih banyak dalam program 
pelatihan, memberi karyawan lebih banyak kesempatan untuk berpartisipasi, dan menyelaraskan sistem kompensasi untuk mendorong karyawan berkontribusi. pengetahuan dan keahlian mereka. Dengan demikian, hasil cukup mendukung Hipotesis 2, yang menyatakan bahwa manajemen stratejik sumber daya manusia berhubungan positif dengan manajemen pengetahuan.

\section{Manajemen}

pengetahuan

mempengaruhi kinerja inovasi, untuk inovasi menunjukkan bahwa perusahaan akan mendapatkan inovasi yang lebih baik ketika perusahaan mengembangkan manajemen pengetahuan mereka dengan baik dalam eksternalisasi, sosialisasi, kombinasi dan interlisasi. Manajemen pengetahuan memiliki pengaruh yang signifikan terhadap inovasi. Dengan demikian, hasil mendukung Hipotesis 3.

Studi ini mengikuti prosedur Baron dan Kenny (1986) untuk menganalisis efek mediasi kapasitas manajemen pengetahuan antara manajemen strtatejik SDM dan inovasi. Empat faktor manajemen stratejik sumber daya manusia memiliki pengaruh positif dan signifikan terhadap manajemen pengetahuan., hasil penelitian menunjukkan pengaruh langsung manajemen pengetahuan terhadap inovasi. Selanjutnya, manajemen pengetahuan secara signifikan mengurangi efek dari faktor-faktor manajemen stratejik sumber daya manusia pada variabel dependen, sebagian besar menjadi tidak signifikan. Temuan menunjukkan bahwa dimasukkannya faktor manajemen pengetahuan melemahkan hubungan antara manajemen stratejik sumber daya manusia dan inovasi. Dengan demikian, manajemen pengetahuan memainkan peran mediasi antara manajemen stratejik SDM dan inovasi, mendukung efek mediasi dalam Hipotesis 4.

\section{Pembahasan}

Studi ini mengkaji peran manajemen pengetahuan dalam hubungan antara manajemen strtaejik sumber daya manusia dan inovasi. Hasil penelitian menunjukkan bahwa praktik stratejik sumber daya manusia berhubungan positif dengan manajemen pengetahuan, yang pada gilirannya berhubungan positif dengan inovasi. Temuan menunjukkan dukungan untuk efek mediasi manajemen pengetahuan pada hubungan antara manajemen stratejik sumber daya manusia dan inovasi. Manajemen stratejik sumber daya manusia bekerja dengan efek menguntungkan mereka pada inovasi melalui akuisisi pengetahuan, berbagi, dan aplikasi. Temuan ini menyoroti peran penting manajemen sumber daya manusia dan manajemen pengetahuan dalam proses inovasi. Implikasi praktis dari hasil ini adalah bahwa manajer perlu secara aktif mengelola sumber daya manusia perusahaan mereka melalui berbagai manajemen stratejik sumber daya manusia untuk merangsang kemampuannya dalam mengelola pengetahuan, berbagi, dan aplikasi pengetahuan. Selain itu, tingkat manajemen pengetahuan yang lebih baik dapat merangsang pemikiran kreatif dan inovatif yang pada akhirnya dapat menghasilkan inovasi yang lebih baik. Untuk memfasilitasi hubungan antara manajemen stratejik sumber daya manusia dan inovasi yang menguntungkan, manajer pertama-tama perlu mengenali pentingnya manajemen pengetahuan. Kemudian mereka harus memanfaatkan manajemen stratejik sumber daya manusia untuk menumbuhkan tingkat manajemen pengetahuan yang lebih baik yang pada gilirannya akan menghasilkan hasil inovasi yang menguntungkan.

Temuan penelitian ini berkontribusi pada pengembangan teoritis model konseptual untuk menjelaskan hubungan antara praktik stratejik sumber daya

This work is licensed under a Creative Commons Attribution-NonCommercial-ShareAlike 4.0 International License. Ciptaan disebarluaskan di bawah Lisensi Creative Commons Atribusi-BerbagiSerupa 4.0 Internasional. 
manusia, manajemen pengetahuan, dan inovasi. Beberapa studi dalam literatur meneliti hubungan dan kekurangan ini serius karena semakin pentingnya inovasi. Oleh karena itu, dari pandangan berbasis pengetahuan, studi ini membangun konsep konseptual model dan hipotesis untuk menunjukkan peran mediasi manajemen pengetahuan antara manajemen stratejik sumber daya manusia dan inovasi.

Kontribusi kedua dari penelitian ini adalah dukungan empiris untuk prediksi model menggunakan data dari kasus-kasus aktual. Meskipun penelitian sebelumnya mengakui pentingnya manajemen sumber daya manusia dalam proses inovasi, tetapi beberapa penelitian secara empiris meneliti efeknya (Jiménez-Jiménez dan Sanz-Valle, 2005; Laursen dan Foss, 2003). Studi ini berkontribusi pada literatur dengan menguji secara empiris hubungan antara praktik stratejik sumber daya manusia, manajemen pengetahuan, dan inovasi. Hasilnya membuktikan bahwa penggunaan praktik stratejik sumber daya manusia termasuk kepegawaian, partisipasi karyawan, sistem penilaian kinerja, dan kompensasi berbasis insentif secara positif menjelaskan inovasi perusahaan; namun, manajemen pengetahuan bertindak sebagai mediator untuk melemahkan hubungan positif ini. Dengan demikian, kami menunjukkan bahwa kapasitas manajemen pengetahuan adalah mekanisme mediasi di mana manajemen stratejik sumber daya manusia menguntungkan inovasi.

Kontribusi ketiga dari hasil penelitian ini diharapkan dapat menjadi masukan pada peningkatan kinerja industri kreatif di Indonesia terutama dalam upaya meningkatkan kualitas sumber daya manusia sehingga mampu bersaing di pasar global.

\section{DAFTAR PUSTAKA}

Andrews MC, Kacmar KM. Discriminating among organizational politics, justice, and support. J Organ Behav 2001 22(4):347-66.

Argote L, McEvily B, Reagans R. Managing knowledge in organizations: an integrative framework and review of emerging themes. Manage Sci 2003 49(4): 571-82.

Atuahene-Gima K. Differential potency of factors affecting innovation perfor- mance in manufacturing and services firms in Australia. J Prod Innov Manag 1996 13(1):35-52.

Baron RM, Kenny DA. The moderatormediator variable distinction in social psychological research: conceptual, strategic, and statistical considerations.

Collins CJ, Clark KD. Strategic human resource practices, top management team social networks, and firm performance: the role of human resource in creating organizational competitive advantage. Acad Manage J 2003 46(6): 740-51.

Currie G, Kerrin M. Human resource management and knowledge management: enhancing knowledge sharing in a pharmaceutical company. Int J Hum Resour Manag 2003 14(6):1027-45.

Damanpour F. Organizational innovation: a meta-analysis of effects of determinants and moderators. Acad Manage J 1991 34(3):555-90.

Davenport TH, Prusak L. Working knowledge, Boston. Harvard Business

Delery JE, Doty DH. Modes of theorizing in strategic human resource management: tests of universalistic, contingency, and configurational performance predictions. Acad Manage J 1996 39(4):802-35. 
Dyer J, Nobeoka K. Creating and managing a high-performance knowledge- sharing network: the Toyota case. Strateg Manage J 2000 21(3):345-67.

Galunic DC, Rodan S. Resource recombinations in the firms: knowledge structures and the potential for Schumpeterian innovation. Strateg Manage J 1998 19(12):1193-201.

Glynn MA. Innovative genius: a framework for relating individual and organizational intelligences to innovation. Acad Manage J 1996 21(4): 1081-111.

Gold AH, Malhotra A, Segars AH. Knowledge management: an organizational capabilities perspective. J Manage Inf Syst 2001 18(1):185-214.

Grant RM. Toward a knowledge-based theory of the firm. Strateg Manage J 1996 17:109-22.

Guthrie JP. High-involvement work practices, turnover, and productivity: evidence form New Zealand. Acad Manage J 2001 44(1):180-90.

Hair Jr JF, Anderson RE, Tatham RC, Black WC. Multivariate Data Analysis. Upper Saddle River, NJ: Prentice-Hall; 1998.

Hamilton B, Nickerson J. Correcting for endogeneity in strategic management research. Strateg Organ 2003 1(1):51-78.

Hansen M. The search-transfer problem: the role of weak ties in sharing knowledge across organizational subunits. Adm Sci Q 1999 44(1):83-111.

Hayes N, Walsham G. Safe enclaves, political enclaves and knowledge working. In: Pritchard C,

Hull R, Chumer H, Willmott H, editors. Managing Knowledge: Critical Investigations of Work and Learning. London:Macmillan; 2000
Henderson R, Cockburn I. Measuring competence: exploring firm effects in pharmaceutical research. Strateg Manage J 1994 15:63-84.

Hurley RF, Hult GTM. Innovation, market orientation, and organizational learning: an integration and empirical examination. J Mark 1998 62(3):42-54

Huselid MA. The impact of human resource management practices on turnover, productivity, and corporate financial performance. Acad Manage J 1995 38(3): 63572.

Ibarra H. Network centrality, power, and innovation involvement: determinants of technical and administrative roles. Acad Manage J 1993 36(3):471-501. Ichniowski C, Shaw K, Prennushi G. The effects of human resource management practices on productivity: a study of steel finishing lines. AmEcon Rev 1997 87(3):291-313.

Jacobs RL, Jones MJ. Structured on-thejob training: unleashing employee expertise in the workplace. San Francisco: Berrett-Koehler; 1995.

Jaw B, Liu W. Promoting organizational learning and self-renewal in Taiwanese companies: the role of HRM. Hum Resour Manag 2003 42(3):223-41.

Jiménez-Jiménez D, Sanz-Valle R. Innovation and human resource management fit: an empirical study. Int J Manpow 2005 26(4):364-81.

Kogut B, Zander U. Knowledge of the firm, combinative capabilities, and the replication of technology. Organ Sci 1992 3:383-97.

Lado AA, Wilson MC. Human resource systems and sustained competitive advantage: a competency-based perspective. Acad Manage Rev 1994 19(4): 699-727. 
Laursen K, Foss NJ. New human resource management practices, complementa- rities, and the impact on innovation performance. Camb J Econ 2003 27(2): 243-63.

Lave J, Wenger E. Situated learning: legitimate peripheral participation. Cambridge: Cambridge University Press; 1991.

Li T, Calantone RJ. The impact of market knowledge competence on new product advantage: conceptualization and empirical examination. J Mark 1998 62(4):13-29.

Lin HF, Lee GG. Impact of organizational learning and knowledge management factors on e-business adoption. Manage Decis 2005 43(2):171-88.

MacDuffie JP. Human resource bundles and manufacturing performance: Organizational logic and flexible production systems in the world auto industry. Ind Labor Relat Rev 1995 48(2):197-221.

Madhavan R, Grover R. From embedded knowledge to embodied knowledge: new product development as knowledge management. J Mark 1998 62(4): $1-12$.

Madsen AS, Ulhøi JP. Technology innovation, human resources and dysfunc- tional integration. Int $\mathbf{J}$ Manpow 2005 26(6):488-501.

Martinsons MG. Knowledge-based systems leverage human resource manage- ment expertise. Int $\mathbf{J}$ Manpow 1995 16(2):17-34.

Mendelson H, Pillai RR. Information age organizations, dynamics, and perfor- mance. J Econ Behav Organ 1999 38:253-81.

Michie J, Sheehan M. HRM practices, $R \& D$ expenditure and innovative investment: evidence from the UK's 1990 workplace industrial relations survey (WIRS). Ind Corp Change 1999 8(2):211-34

Montes FJL, Moreno AR, Fernandez LMM. Assessing the organizational climate and contractual relationship for perceptions of support for innovation. Int J Manpow 2004 25(2):167-80.

Moorman C, Miner AS. Organizational improvisation and organizational memory. Acad Manage Rev 1998 23(4):698-723.

Mueller F, Dyerson R. Expert humans or expert organizations? Organ Stud 1999 20(2):225-56.

Mumford MD. Managing creative people: strategies and tactics for innovation. Hum Resour Manage Rev 2000 10(3):313-51.

Nonaka I, Konno N. The concept of 'Ba': building a foundation for knowledge creation. Calif Manage Rev 1998 40(3):40-54.

Nonaka I, Takeuchi H. The knowledgecreating company. New York: Oxford University Press; 1995.

Pfeffer J. Seven practices of successful organizations. Calif Manage Rev 1998 40(2):96-123.

Podsakoff P, Organ D. Self-reports in organizational research: problems and prospects. J Manage 1986 12(4):531-44.

Ruggles R. The state of the notion: knowledge management in practice. Calif Manage Rev 1998 40(3):809.

Sarin S, McDermott C. The effect of team leader characteristics on learning, knowledge application, and performance of crossfunctional new product development teams. Decis Sci 2003 34(4):707-39.

Scarbrough H. Knowledge management, HRM and the innovation process. Int J Manpow 2003 24(5):501-16. 
Scarbrough H, Carter C. Investigating knowledge management. London: CIPD; 2000.

Schumpeter J. The theory of economic development: an inquiry into profits, capital, credit, interest and the business cycle (R Opie, Trans.). London: Oxford University Press; 1912/1934.

Spender JC. Making knowledge the basis of a dynamic theory of the firm.Strateg Manage J 1996 17(10):45-62.

Subramaniam M, Youndt MA. The influence of intellectual capital on the types of innovative capabilities. Acad Manage J 2005 48(3):450-63.

Swanson RA. Analysis for improving performance: tools for diagnosing organizations and documenting workplace expertise. San Francisco: Berrett- Koehler; 1994.

Szulanski G. Exploiting internal stickiness: impediments to the transfer of best practice. Strateg Manage J 1996 17:27-43.

Tannenbaum SI, Dupuree-Bruno LM. The relationships between organizational and environmental factors and the use of innovative human resource practices. Group Organ Manage 1994 19(2):171202.

Torraco RJ, Swanson RA. The strategic roles of human resource development.Hum Resour Plann 1995 18(4):10-21.

Tsai W. Social structure of "competition" within a multiunit organization: coordination, competition, and intra-organizational knowledge sharing. Organ Sci 2002 13(2):17990.

Tsai W. Knowledge transfer in intraorganizational networks: effects of network position and absorptive capacity on business unit innovation and performance. Acad Manage J 2001 44(5):996-1004.
Tsai W, Ghoshal S. Social capital and value creation: the role of intrafirm networks. Acad Manage J 1998 41(4):462-76.

Teece, D. J., Pisano, G., \& Shuen, A. (1997). Dynamic capabilities and strategic management. Strategic Management Journal.

Von Krogh G. Care in knowledge creation. Calif Manage Rev 1998 40(3): 133-53.

Weisberg RW. Expertise and reason in creative thinking: evidence from case studies and the laboratory. In: Kaufman JC, Baer J, editors. Creativity and Reason in Cognitive Development. Cambridge: Cambridge University Press; 2006.

Wooldridge J. Econometric analysis of cross section and panel data. Cambridge Massachusetts: The MIT Press; 2002.

Wright PM, Dunford BB, Snell SA. Human resources and the resourcebased view of the firm. J Manage 2001 27(6):701-21.

Yli-Renko H, Autio E, Sapienza HJ. Social capital, knowledge acquisition, and knowledge exploitation in young technologybased firms. Strateg Manage J 2001 22(6/7):587-613.

Youndt MA, Snell SA, Dean JW, Lepak DP. Human resource management, manufacturing strategy, and firm performance. Acad Manage J 1996 39(4): 836-66.

This work is licensed under a Creative Commons Attribution-NonCommercial-ShareAlike 4.0 International License. 